\title{
FACTORS BEHIND TRADE CREDIT FINANCING OF SMEs IN CROATIA
}

\author{
Sandra Pepur \\ PhD, Assistant Professor, University of Split, Faculty of Economics, Business and Tourism, Cvite Fiskovića 5, \\ 21000 Split, Croatia; e-mail: sandra.pepur@efst.hr
}

\section{Dujam Kovač}

Mag. oec., Assistant Lecturer, University of Split, Faculty of Economics, Business and Tourism, Cvite Fiskovića 5, 21000 Split, Croatia; e-mail: dujam.kovac@efst.hr

\section{Marijana Ćurak}

PhD, Full Professor, University of Split, Faculty of Economics, Business and Tourism, Cvite Fiskovića 5, 21000 Split, Croatia; e-mail: marijana.curak@efst.hr

\begin{abstract}
Small and medium enterprises (SMEs) contribute to the national economy in terms of employment, added value, knowledge generation, and innovation. However, their potential and in the case of economic downturns even their survival is affected by the difficulties in their access to external financing under acceptable terms and adequate timing and amount. In the case of asymmetric information problems, which make SMEs more sensitive to financial market imperfections, trade credit can be a valuable source of financing. In the European Union, trade credit is among the most relevant external funding sources and it is among the most important alternatives to financial intermediaries' financing. However, there are substantial differences between the countries with respect to availability and use of trade credit. Therefore, this research examines determining (company-specific and country-specific) factors behind the use of trade credit as a financing source in Croatia. The empirical analysis is based on the data for 1,225 SMEs operating in Croatia in the period from 2008 to 2017 and is done using the panel data methodology. The findings confirm that firms' characteristics, as well as the characteristics of financial, macroeconomic and legal environment in which the firms operate, influence the use of trade credit in SMEs in Croatia. The paper contributes to relatively scarce empirical evidence on the determinants of trade credit use by SMEs in South-East European countries.
\end{abstract}

Key words: Supplier financing, Croatian companies, panel methodology 


\section{INTRODUCTION}

Small and medium sized enterprises (SMEs) are an important part of every national economy ${ }^{1}$. In 2017, in the EU-28 non-financial business sector, SMEs accounted for over $99 \%$ of enterprises, over $66 \%$ of employment and generated almost $57 \%$ of total value added (European Commission, 2018:13). With regard to Croatia, in 2017 SMEs accounted for $99.7 \%$ of total enterprises, employed $73.2 \%$ of the workforce and contributed with a share of $59.6 \%$ to the total income generated (Alpeza et al., 2018; FINA, 2018). Additionally, SMEs are important in terms of knowledge generation and research as well as their innovation potential (Leitner, Stehrer, 2015:1).

However, their own investments and development as well as their contribution to the economic growth can be limited by the obstacles SMEs face in their business. According to different surveys, one of the most relevant barriers for SMEs is access to finance which includes external financing under acceptable terms and in adequate amount (Vidučić et al., 2018:487). In a bank-oriented financial system such as the Croatian one, SMEs are more directed to traditional financing through financial intermediaries. Although the range of bank credits has broaden in recent years, many financial institutions consider lending to SMEs to be highly risky, primarily due to poor collateral, high failure rate and/or lack of information (Vidučić et al., 2018). This consequently results in inadequate financing in different phases of SMEs' development, especially in the risky start-up phase or during the phase of intensive growth (Alpeza et al., 2018). It becomes even more pronounced in turbulent times.

In such circumstances, when SMEs cannot obtain a credit from a bank or can obtain it but only at high costs and after very complex procedures, trade credit or supplier financing becomes the valuable alternative. Recent evidence confirms the importance of trade credit financing for SMEs in the European Union - trade credit is one of the largest sources of financing, amounting to around $30 \%$ of the GDP. It is the most important alternative to bank loans as it is the principal source of financing after sources through financial intermediaries, and it is present at all stages of a firm's lifecycle (CantoCuevas et al., 2019:1).

Trade credit is an attractive financing source and it allows a customer (buyer) to obtain a product (or service) up front while the payment to supplier is deferred and will take place in the future, on a scheduled day, with no interest charged ${ }^{2}$. The theoretical literature suggests various approaches and motives ${ }^{3,4}$ to explain the firms' involvement in tradecredit("supply-sideview" which focuses on trade

1 The criteria for classifying companies in the SME sector in Croatia are defined by the Accounting Act (Zakon o računovodstvu) and the Small Business Incentives Act (Zakon o poticanju malog gospodarstva). The latest amendment to the Accounting Act in 2017 introduced the category of micro-enterprises. The criteria for the classification are annual number of employees, the annual income or the balance sheet total.

2 One type of costs connected to trade credit financing is an implicit cost that the company-buyer bears in a situation when it forgoes a discount for early payment offered from the supplier. Apart from these, trade credit can expose company-buyer to refinancing risk, potential costs such as late payment penalties, lowering the firm's credit reputation etc., which can ultimately lead to worsening the relationship with suppliers (Martinez-Sola et al., 2017).

3 The motives are described as operational, commercial and financial. For literature review, see for example Emery (1984) and Petersen, Rajan (1997).

4 Another strand of empirical literature, such as the recent study by Mättö and Niskanen (2019), investigate trade credit use through the prism of cultural dimensions. Their findings indicate that religion and national culture can determine trade credit management and, to a certain extent, explain previously observed cross-country variations in trade credit (Mättö, Niskanen, 2019). 
credit granted to customers and is evident in the level of accounts receivable) and the advantages of the use of trade credit as a financing source ("demand-side view" shown in the buyer's balance sheet level of accounts payable). Trade credit allows companies to reduce the transaction costs related to cash management and the process of paying invoices (Ferris, 1981; Emery, 1987) and to evaluate the product quality before payment (Lee, Stowe, 1993; Deloof, Jegers, 1996). In this way, it supports the sales policy, enables flexibility with respect to the variability in demand (Emery, 1984) and can strengthen the long-term relationship with customers (Wilson, Summers, 2002). Financial approach observes trade credit as an alternative to bank credit and other sources of financing, emphasizing market imperfections, such as transaction costs and information asymmetry. Market imperfections may result in credit rationing and, to overcome this problem, SMEs can choose trade credit as an important short-term financing instrument (Yazdanfar, Öhman, 2017), especially when credit from financial institutions is constrained (Elliehausen, Wolken, 1993; Petersen, Rajan, 1997) or when financial markets are less developed (Fisman, Love, 2003). In comparison to bank loans, trade credit provides a higher degree of financial flexibility (Huyghebaert et al., 2001).

However, if the discount for early payments is not used (Vidučić et al., 2018; Hill et al, 2017) s $^{5}$ suppliers' financing can be a very expensive source of financing with high opportunity costs. Although some studies suggest the opposite, the findings of a recent international study by Hill et al. (2017) suggest that trade credit is used relatively less by larger, more liquid firms and firms with less volatile earnings, or, more generally, by firms with easier access to financial credit. These results, which are more pronounced in firms operating in emerging economies, support the position of trade credit as an expensive source of financing (Hill et al., 2017:2319). The aforementioned additionally justifies the investigation of the key factors that determine the use of expensive trade credit by SMEs in South-East European countries such as Croatia.

In recent years, the number of researches on different aspects of trade credit use and/or its implications on company performance (profitability, value, survival, etc.) have increased (Yazdanfar, Öhman, 2017:11). Additionally, after the last financial crisis, several studies examined whether trade credit is an alternative or a complement to other financing sources (and bank credit). Generally, the results support the role of trade credit as a complement to (short-term) bank financing (Andrieu et al., 2018; Yazdanfar, Öhman, 2017) but also as a substitute for long-term debt (Yazdanfar, Öhman, 2017). In other words, the results indicate a redistribution effect of trade credit during financial crisis denoting that as the SME's access to finance from financial institutions was restricted, SMEs relied more on trade credit, which then increased the possibility of their survival during and after the crisis period (McGuinness et al., 2018). Thus, trade credit proved to be an important mechanism that helped SMEs to cope with the credit crisis (McGuinness, Hogan, 2014; McGuiness et al., 2018; Bussoli, Marino, 2018) as suppliers served as lenders of last resort (Carbo-Valverde et al., 2016).

All the above mentioned supports a deeper investigation of trade credit as an SME funding source, apart from solely bank financing. Therefore, the aim of this research is to empirically investigate the

5 However, the decision on forgoing the discount is not completely voluntary made and can be closely related to the firm's inadequate liquidity and inability to take the discount offered.

6 For the review of these studies, see for example Hill et al. (2017) 
determinants of trade credit financing of SMEs in Croatia. The role of trade credit and the factors behind it, can be especially pronounced in the bank-oriented financial system like the Croatian one, where firms depend on limited and expensive bank financing. Additionally, financing through capital markets is unreachable and is therefore rarely used.

Firms' access to finance depends not only on the characteristics of the firm itself, but also on the environment in which it operates. Beck et al. (2008) show in a research on a large set of developed and developing countries that the use of external sources strongly depends on the country's level of financial and legal development. In developing countries where formal lenders are limited, financial markets are less developed and creditor protection is weak, trade credit plays an even more significant role in funding firm's activities (Fishman, Love, 2003). With respect to the EU countries, despite economic and financial integration of new member states, both macroeconomic context and the structure of the banking sector still differ significantly between the member states (Leitner, Stehrer, 2015). According to SAFE survey, the financing patterns of SMEs differ substantially in EU-28 and Croatia due to differences in the financing resource availability and the SMEs' needs (Harc et al., 2017). Furthermore, firms from Croatia have rarely been included 7 in the cross-country examination on trade credit use. To the authors' knowledge, the only single-country research on trade credit determinants performed on a sample of Croatian companies is a study by Deari and Barbuta-Misu (2018). Their sample consisted of 26 non-financial firms listed on the Zagreb Stock Exchange during the observed period from 2007 to 2013. Our research differs from the mentioned study as it focuses on a larger sample of small and medium enterprises and for a longer and more recent period from 2008 to 2017. Apart from the firm-level determinants used in the study by Deari and Barbuta-Misu (2018), our analysis will be expanded to include institutional and macroeconomic characteristics that may affect firm's financial decisions, such as the features of the financial system, legal environment and general macroeconomic circumstances. Additionally, our analysis is performed using dynamic panel methodology and the GMM estimator.

All the above mentioned raises the question of whether the trade credit use and its determinants, confirmed in other comparable studies, differ in the case of small and medium enterprises in a specific Croatian environment. Thus, the main hypothesis of the research is: firm-specific factors (internal) as well as institutional and macroeconomic (external) factors influence the use of trade credit as a financing source of SMEs in Croatia.

The paper is structured as follows: after the introduction, the second section briefly outlines the literature review on various factors that explain the use of trade credit financing. The third section describes the data, methodology and the research model. Empirical results and their discussion are presented in the fourth section, followed by the concluding remarks.

7 Croatia has been included only in a few cross-country analysis: in a study by Bussoli and Marino (2018) but contributed only with nine small and medium companies in the final sample; then in an international study by Hill et al. (2017) but with only 129 observations ( $0.075 \%$ in total observations) in eighteen-year period; and in the Mättö and Niskanen's (2019) cross-country study on the relationship between religion and nation culture and trade credit (6,603 observations in a five-year period or $1.29 \%)$. 

Zbornik Veleučilišta u Rijeci, Vol. 8 (2020), No. 1, pp. 59-76

\section{DETERMINANTS OF TRADE CREDIT - LITERATURE REVIEW}

Many empirical investigations on trade credit use, its importance and influential factors have been carried out lately. Evidence is obtained using different approaches (microeconomic or macroeconomic), different variables and their measures, different methods, sources of data (survey results or firm-level accounting data), and different time spans.

Firm's characteristics, such as creditworthiness, profitability, current asset investment, growth opportunities as well as access and availability of alternative financing sources, can influence the use of trade credit.

According to the Pecking order theory (Myers, Majluf, 1984; Myers 1984), which is based on the asymmetric information between the firm's insiders and outsiders and results in adverse selection problem, firms prefer internal to external financing and debt over equity. Comparing internal financing and trade credit, it is concluded that internal financing is preferred because it is the cheapest source and it avoids all information asymmetry problems. Thus, firms with a better ability to generate funds internally have more resources available and need less funding from other sources, including suppliers. This negative relationship is confirmed in most previous studies conducted on SMEs (i.e. García-Teruel, Martínez Solano, 2010; Martinez-Sola et al., 2017; Canto-Cuevas et al., 2019).

Growth opportunities put pressure on the amount of working capital the firm needs to support sales growth. Thus, companies with a larger increase in sales demand more finance in general and trade credit in particular because of its flexibility to adjust to the customer's operation dynamics. As Cuñat (2007) points out, high growth firms get a higher proportion of trade credit from their suppliers. Therefore, a positive relationship is expected between SMEs' sales growth and trade credit financing, as confirmed by Palacin-Sánchez et al. (2018), Mättö and Niskanen (2019), and Canto-Cuevas et al. (2019).

In assessing a firm's ability to obtain credit, its creditworthiness is of the highest importance. The size of the firm is one of the credit quality indicators and it can affect the demand for trade credit financing adversely. Firm size reflects the degree of information asymmetry and the ability to establish relationships with both banks and other credit suppliers (Yazdanfar, Öhman, 2017). Larger firms are considered more creditworthy and can therefore receive more credit from their suppliers (Petersen, Rajan, 1997). This positive relationship is supported by the results reported in studies conducted by Yazdanfar and Öhman (2017), Barbuta-Misu (2018) and Canto Cuevas et al. (2019), who found that larger firms, with greater growth opportunities and greater investments in current assets, receive more financing from their suppliers. However, due to their better credit capacity and reputation, larger firms have easier access to financing through other credit channels and consequently need less trade credit (i.e. Niskanen, Niskanen, 2006; Bussoli, 2017).

The level of inventory and its management is a part of the firm's working capital management. Firms that invest more in inventories, similarly to firms with a greater increase in sales, need more short-term financing. On the assumption that firms tend to match the maturity of assets and liabilities, in order to finance investments in working capital and satisfy the mentioned financing 
rule, it can be expected that the trade credit financing increases with the growth in inventories. Empirical results confirm this positive relationship (i.e. Garcia-Teruel, Martinez-Solano, 2010; Deari, Barbuta-Misu, 2018). However, inventories can serve as collateral for bank loans, thus reducing firm's credit constraints (Atanasova, 2007) and decreasing the need for supplier financing. Moreover, a composition of inventories can also affect firm's decision to use trade credit (i.e. Mateut et al., 2015) because different inventory categories ${ }^{8}$ have different values from the liquidation perspective.

In line with the Pecking order theory, internal funds are the cheapest source of financing and are therefore preferred. Firms with higher profitability tend to have more internally generated funds that consequently reduce their need for more expensive trade credit financing. In most empirical studies, this negative relationship is evident (i.e. Canto-Cuevas et al. 2016, Yazdanfar, Öhman, 2016; Andrieu et al. 2018).

The financing motive behind the involvement in trade credit emphasises the advantages of supplier financing in the context of availability of other sources of financing, particularly bank credit. This implies a potential influence of, not only firm's characteristics, but also of institutional features, such as the characteristics of a country's financial system. Financial system has an important role in reducing market imperfections related to transaction costs, information asymmetry and conflict of interest and in providing external financing for companies. When considering banks as the main providers of firms' financing, the relationship between bank credit and trade credit is explained by two opposing views. The first one sees trade credit as an alternative to bank loan? According to Pagano (1993), in the process of funnelling savings from savers to borrowers, a part of the funds is lost due to covering the costs of financial intermediation. When banks are considered, these funds cover the spread between the lending and borrowing interest rates. It is a compensation for banking services. Although the spread is determined by various factors (e.g. market terms, taxation, regulation), it also reflects the bank's efficiency. If banks are less efficient, the cost of financial intermediation is higher. From the firms' perspective, this means higher cost of borrowing which results in higher trade credit financing. Additionally, due to limited amount of collateral, access to bank credit is especially limited for SMEs. Moreover, these companies have only a partial access to the financial markets. Thus, as it was stated in the seminal work by Meltzer (1960) and confirmed by numerous studies (e.g. McGuinness, Hogan, 2014; Carbó-Valverde et al., 2016; Palacín-Sánchez et al., 2018), with restricted banks' financing sources, firms resort to trade credits. The tightening in banks' lending, especially to SMEs, was evident in times of financial crises when firms used more trade credits (Casey, O'Toole 2014; McGuinness et al., 2017). However, there is the opposite evidence, too. More precisely, empirical studies confirm that during financial crises bank credit and trade credit move in the same direction (Taketa, Udell 2007; Psillaki, Eleftheriou, 2015). This is in line with the opposite view ${ }^{10}$, which implies that the relationship between trade credit and bank credit is positive (Biais, Gollier, 1997). Banks are readier to lend if suppliers provide trade credits to their customers. In other words, trade credits by suppliers reduce information

8 To test the impact of inventory composition on firm's incentive to use trade credit, separate accounting information on inventories according to their stage of fabrication is needed. These disaggregated data are not available in dataset used in this study.

9 In the literature known as substitution hypothesis.

10 In the literature known as hypothesis of complementarity. 
asymmetry for banks. In this way, as trade credits are increasing, bank lending is increasing, too. Additionally, with more access to bank financing, suppliers of trade credit are more able to provide financing to their customers. In this way, "non-financial corporations act as 'agents' for financial intermediaries" (Demirgüç-Kunt, Maksimovic, 2001:6). This is the case when suppliers are more efficient in gathering information and monitoring firms in comparison to financial institutions. Thus, these two types of financing are not alternative but are complementary to one another. Beside the above stated papers, there are additional studies that empirically confirm the second hypothesis (e.g. Agostino, Trivieri, 2014; Deloof, La Rocca, 2015; Andrieu et al., 2018; Hill et al., 2019).

Beside the above explained influences of company-level factors and the characteristics of the financial system, the use of trade credit can also be determined by the macroeconomic factors and the legal environment.

Macroeconomic conditions influence external financing (Demirgüç-Kunt, Maksimovic, 1998; Demirgüç-Kunt, Maksimovic, 2001). Among them, two main ones are GDP growth and inflation. When the economy is growing, firms need more financial resources. Thus, it is expected that economic growth positively affects trade credit. Since inflation reflects monetary instability, longterm financing is limited in times of high inflation implying that firms have access only to shortterm financing, and consequently to trade credit. Demirgüç-Kunt and Maksimovic (1998) found that long-term debt is negatively related to inflation. Therefore, a positive relationship between inflation and trade credit is anticipated.

A country's legal system influences the availability of external sources of financing (DemirgüçKunt, Maksimovic, 1998). In countries with low level of creditor rights protection, lenders refrain from providing financial resources to firms. On the other hand, a more efficient legal system that protects creditor rights encourages repayment of both banks and trade credits. This could imply that a positive impact of the legal system on trade credit is expected. However, the legal system is likely to be more important for credits of financial intermediaries than for trade credits (DemirgüçKunt, Maksimovic, 2001). In the environment of an inefficient legal system, the suppliers of trade credit are more able to cope with the problem of credit repayment in comparison to banks. According to Fishman and Love (2003:357) the advantages of trade creditors in comparison to financial institutions in countries with inefficient legal systems are information acquisition, the renegotiation/liquidation process and enforcement. For example, suppliers could suspend deliveries to their customers in the future and thus encourage the repayment of trade credit. This suggests that a negative relationship between the efficiency of the legal system and trade credit is expected (Demirgüç-Kunt, Maksimovic, 2001). The efficiency of the legal system as a determinant of trade credit is evidenced by Demirgüç-Kunt and Maksimovic (2001), Hill et al. (2017) and Palacín-Sánchez et al. (2018).

\section{DATA AND METHODOLOGY}

Data for the variables used in this analysis are collected for the 2008-2017 period from the Amadeus - Bureau van Dijk database. The analysed period represents the most recent available data that refer to small and medium enterprises in Croatia. Size classification is based on the Amadeus - 
Bureau van Dijk database criteria. Medium-sized enterprises are those that satisfy at least one of the following criteria: operating income $\geq 1$ million EUR, total assets $\geq 2$ million EUR, number of employees $\geq 15$. When the indicators are lower than the previously stated ones, then the data refers to a small business. After excluding SMEs with missing data and applying the criteria that for each variable there should be data available for a minimum of 3 consecutive years, the final number of active companies represented in the analysis is 1,225 , which represents $1.02 \%$ of the SME population in 2017.

The advantage of panel data is based on the fact that they contain inter-individual differences and intra-individual dynamics which impose an advantage over cross-sectional or time-series data (Hsiao, 2005). The advantage is a more precise model parameters estimation. According to Hsiao (1985) panel data reduce estimator bias, while simultaneously reducing problems of data multicollinearity. Due to the dynamic nature of economic relations, the following dynamic model is formed:

$$
\text { creditpay }_{i,}=\mu+\gamma \text { creditpay }_{i, t-1}+\sum \beta_{\mathrm{j}} \mathrm{X}_{\mathrm{j}, t}+\varepsilon_{i, t}
$$

Where creditpay, is the measure of the size of trade credit use of an SME $i$ at time $t$, with $i=1, \ldots, 1225$, $t=1, \ldots, 10 ; \mu$ is the constant term, creditpay $_{i, t-1}$ is the one-period lagged size of trade credit use, $\gamma$ is the lagged dependent variable parameter, the vector of $j$ explanatory variables accounts for the firm's specific financial system, macroeconomic and institutional variables, $\varepsilon_{i, t}$ is the disturbance, which summarizes unobserved firm-specific effect and idiosyncratic error.

In order to estimate the impact of various factors that may have an important role in explaining trade credit financing, the authors created two groups of determinants; the first relates to firm-level determinants and the other to country-level determinants. A detailed insight into determinants, their measures and their expected effect on trade credit use is presented in Table 1. 
Table 1. Definition, measure and expected impact of the variables

\begin{tabular}{|c|c|c|c|c|}
\hline Variable & Variable measure & Source & $\begin{array}{l}\text { Variable } \\
\text { code }\end{array}$ & $\begin{array}{c}\text { Expected } \\
\text { impact }\end{array}$ \\
\hline Trade credit & Credit payables / Total assets & $\begin{array}{l}\text { Amadeus - Bureau } \\
\text { van Dijk database }\end{array}$ & creditpay & \\
\hline \multicolumn{5}{|c|}{ Firm-level data } \\
\hline Internal financing & $\begin{array}{c}(\mathrm{P} / \mathrm{L} \text { for period }[=\mathrm{Net} \\
\text { Income }]+ \text { depreciation }) / \mathrm{TA}\end{array}$ & \multirow{7}{*}{ 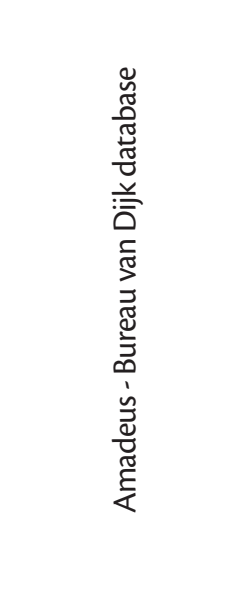 } & cashf & - \\
\hline Short term debt & Short term debt / Total assets & & shortd & $+/-$ \\
\hline Long term debt & Long term debt / Total Assets & & longd & $+/-$ \\
\hline Creditworthiness & Ln_total assets & & size & $+1-$ \\
\hline Profitability & $\begin{array}{l}\text { EBITDA Margin \% (EBITDA / } \\
\text { Operating revenue) }\end{array}$ & & profit & $+1-$ \\
\hline $\begin{array}{l}\text { Growth } \\
\text { opportunities }\end{array}$ & $\begin{array}{c}\text { (Sales } \mathrm{t} \text { - Sales } \mathrm{t}-1) / \text { Total } \\
\text { assets } \mathrm{t}-1 \text { ) }\end{array}$ & & growth & + \\
\hline Inventory & Ln_inventory & & invent & + \\
\hline \multicolumn{5}{|c|}{ Country-level data } \\
\hline Bank efficiency & $\begin{array}{l}\text { Bank overhead costs to total } \\
\text { assets }(\%)\end{array}$ & $\begin{array}{l}\text { World Bank, } \\
\text { International } \\
\text { Monetary Fund, } \\
\text { International } \\
\text { Financial Statistics } \\
\text { and data files } \\
\end{array}$ & gfddei & + \\
\hline GDP growth & $\begin{array}{l}\text { Growth rate of GDP per } \\
\text { capita, } \\
\text { PPP (constant 2011 } \\
\text { international \$) }\end{array}$ & $\begin{array}{c}\text { World Bank, } \\
\text { national accounts } \\
\text { data and OECD } \\
\text { National Accounts } \\
\text { data files }\end{array}$ & g_gdp & + \\
\hline Inflation & $\begin{array}{l}\text { Inflation, consumer prices } \\
\text { (annual \%) }\end{array}$ & $\begin{array}{c}\text { World Bank, } \\
\text { International } \\
\text { Monetary Fund, } \\
\text { International } \\
\text { Financial Statistics } \\
\text { and data files }\end{array}$ & infln & + \\
\hline Legal system & Property rights index & $\begin{array}{l}\text { Property Rights } \\
\text { Alliance }\end{array}$ & proprights & - \\
\hline
\end{tabular}


Table 2 provides an insight into descriptive statistics of the analysed variables. The average share of trade credit financing in the total assets for SMEs in Croatia in the observed 2008-2017 period amounted to $19.4 \%$. Interesting to note, some SMEs in the sample used trade credits to an extent twice the recorded total assets.

Table 2. Descriptive statistics

\begin{tabular}{cccccc} 
Variable & Obs & Mean & $\begin{array}{c}\text { Std. } \\
\text { Dev. }\end{array}$ & Min & Max \\
\hline creditpay & 12,050 & 0.194 & 0.183 & $3.73 \mathrm{E}-06$ & 2.221 \\
shortd & 4,366 & 0.088 & 0.095 & $3.25 \mathrm{E}-06$ & 0.963 \\
longd & 7,793 & 0.221 & 0.218 & $1.86 \mathrm{E}-06$ & 6.986 \\
size & 12,128 & 15.095 & 1.448 & 7.090 & 19.307 \\
\hline & & & & & \\
growth & 10,800 & 0.650 & 43.911 & -1.000 & $4,476.600$ \\
invent & 9,700 & 12.977 & 2.086 & 2.303 & 18.038 \\
cashf & 11,947 & 0.129 & 0.211 & -14.303 & 1.708 \\
profit & 11,894 & 0.113 & 0.148 & -0.986 & 0.925 \\
\hline & & & & & \\
gfddei & 11,025 & 2.245 & 0.210 & 1.998 & 2.757 \\
g_gdp & 12,250 & 1.006 & 0.033 & 0.927 & 1.040 \\
infln & 12,250 & 1.666 & 2.010 & -1.125 & 6.077 \\
proprights & 12,250 & 59.210 & 2.460 & 54.100 & 61.500 \\
\hline
\end{tabular}

Source: Authors

According to Baltagi (2008), panel analysis does not presuppose the multicollinearity test, hence the possible multicollinearity problem is analysed. Table 3 summarizes the pair-wise correlation coefficient for all the variables that have been included in the model. There is no pronounced correlation between the explanatory variables, which indicates that there is no problem of multicollinearity. 
Table 3. Correlation matrix

\begin{tabular}{|c|c|c|c|c|c|c|}
\hline & creditpay & cashf & shortd & longd & size & profit \\
\hline creditpay & 1 & & & & & \\
\hline cashf & -0.148 & 1 & & & & \\
\hline shortd & 0.038 & -0.08 & 1 & & & \\
\hline longd & -0.187 & -0.027 & -0.154 & 1 & & \\
\hline size & -0.053 & -0.11 & -0.157 & -0.03 & 1 & \\
\hline profit & -0.253 & 0.552 & -0.115 & 0.101 & 0.055 & 1 \\
\hline growth & -0.003 & -0.002 & 0.036 & -0.011 & 0.001 & 0.029 \\
\hline invent & 0.095 & -0.183 & -0.015 & -0.078 & 0.546 & -0.121 \\
\hline gfddei & -0.019 & 0.012 & -0.019 & -0.01 & 0 & 0.023 \\
\hline g_gdp & -0.068 & -0.023 & -0.034 & -0.003 & 0.017 & 0.01 \\
\hline infln & 0.08 & 0.044 & 0.084 & 0.019 & -0.011 & 0.023 \\
\hline \multirow[t]{2}{*}{ proprights } & -0.057 & -0.047 & -0.053 & -0.012 & 0.013 & -0.048 \\
\hline & growth & invent & gfddei & g_gdp & infln & proprights \\
\hline growth & 1 & & & & & \\
\hline invent & -0.027 & 1 & & & & \\
\hline gfddei & -0.008 & -0.003 & 1 & & & \\
\hline g_gdp & 0.011 & -0.003 & 0.221 & 1 & & \\
\hline infln & 0.002 & 0.017 & -0.036 & -0.267 & 1 & \\
\hline proprights & -0.001 & -0.007 & -0.071 & 0.352 & -0.551 & 1 \\
\hline
\end{tabular}

Source: Authors

\section{RESULTS AND DISCUSSION}

In this section, the empirical results and discussion are presented. Two models are estimated: the first underlying model contains firm-level variables while country-level variables are added in the second one. The models are estimated with the Blundell-Bond estimator. The estimation results are shown in Table 4. Based on the assumption of the relationship between the dependent and some of the explanatory variables in both directions, a part of the explanatory variables is assumed to be endogenous. They include: short-term debt, long-term debt, size, growth of sales, and inventories. The validity of each model is tested using the Sargan test. The performed Sargan test does not show the presence of endogenous problems. According to Roodman (2009), Sargan test is valid in the case when the number of instruments does not exceed the number of groups. This condition is also met. 
Another diagnostic test refers to the autocorrelation of residuals (first-order serial correlation and second-order serial correlation). The autocorrelation tests confirm the consistency of the estimator.

Table 4. Estimation results

\begin{tabular}{|c|c|c|}
\hline & BB Two-step & BB Two-step (country-level data included) \\
\hline & creditpay & creditpay \\
\hline \multirow[t]{2}{*}{ L.creditpay } & $0.504^{* * *}$ & $0.533^{* * *}$ \\
\hline & -0.0307 & -0.0387 \\
\hline \multirow[t]{2}{*}{ shortd } & $-0.113^{*}$ & $-0.133^{* *}$ \\
\hline & -0.0631 & -0.0607 \\
\hline \multirow[t]{2}{*}{ longd } & -0.0427 & -0.0265 \\
\hline & -0.0294 & -0.0257 \\
\hline \multirow[t]{2}{*}{ size } & $-0.0157^{* *}$ & $-0.0189^{* * *}$ \\
\hline & -0.00616 & -0.00704 \\
\hline \multirow[t]{2}{*}{ growth } & 0.00374 & 0.00305 \\
\hline & -0.00297 & -0.00277 \\
\hline \multirow[t]{2}{*}{ invent } & 0.00197 & $0.00952^{* *}$ \\
\hline & -0.00384 & -0.00419 \\
\hline \multirow[t]{2}{*}{ cashf } & $-0.107^{* * *}$ & $-0.0948^{* * *}$ \\
\hline & -0.0375 & -0.0349 \\
\hline \multirow[t]{2}{*}{ profit } & $-0.0466^{* *}$ & $-0.0365^{*}$ \\
\hline & -0.0217 & -0.0198 \\
\hline \multirow[t]{2}{*}{ gfddei } & & $0.00952^{* *}$ \\
\hline & & -0.00481 \\
\hline \multirow[t]{2}{*}{ g_gdp } & & $0.168^{* *}$ \\
\hline & & -0.0704 \\
\hline \multirow[t]{2}{*}{ infln } & & $0.00314^{* * *}$ \\
\hline & & -0.00109 \\
\hline \multirow[t]{2}{*}{ proprights } & & $-0.00334^{* * *}$ \\
\hline & & -0.00102 \\
\hline \multirow[t]{2}{*}{ _cons } & $0.344^{* * *}$ & $0.293^{* * *}$ \\
\hline & -0.0813 & -0.0989 \\
\hline $\mathrm{N}$ & 2640 & 2349 \\
\hline Sargan test ( $p$-value) & 0.0634 & 0.0782 \\
\hline First-order correlation ( $p$-value) & 0 & 0 \\
\hline Second-order correlation ( $p$-value) & 0.5588 & 0.6987 \\
\hline
\end{tabular}

${ }^{*} \mathrm{p}<0,05,{ }^{* * *} \mathrm{p}<0,01$ 
The impact of the analysed explanatory variables is in line with theoretical expectations. The results confirm that SMEs that generate more internal finance demand less trade credit. This negative relationship is confirmed in most previous studies conducted on SMEs (i.e. García-Teruel, Martínez Solano, 2010; Martinez-Sola et al., 2017; Canto-Cuevas et al. 2019). The negative coefficients with regard to short-term and long term-debt indicate a substitutive relation between trade credit and these alternative sources of financing. The availability of short-term debt reduces the need for trade credit which is more costly and thus less preferable. Although the same negative relationship holds for long-term debt as well, it is not statistically significant. Similar results are confirmed in other studies on SMEs, i.e. Garcia-Teruel and Martinez-Solano (2010), Yazdanfar and Öhman (2017) (substitution effect is evident only for the long-term debt) and Canto-Cuevas (2019). With respect to firm size, the results confirm that larger SMEs, which are observed as more creditworthy, tend to use less trade credit. With regard to firm profitability, it is concluded that profitable firms, due to their ability to generate internal funds, use less financing from suppliers. Firms with growth opportunities and larger inventories use trade credit more in order to finance their investments in working capital. The statistical significance of the latter is confirmed. Our results regarding the impact of firm profitability and sales growth correspond to the results of the aforementioned studies (i.e. Garcia-Teruel, Martinez-Solano, 2010; Yazdanfar, Öhman, 2017; Canto-Cuevas, 2019).

The coefficient of bank efficiency variable has a positive sign. Taking into consideration the measure of the bank efficiency variable, this implies that as banks are becoming less efficient, trade credits are increasing. In other words, the obtained results confirm the role of trade credit as a substitution for bank financing and are in line with the results of the following country-level studies: Nilsen (2002), McGuinness and Hogan (2014) and Carbó-Valverde et al. (2016).

Considering macro-economic conditions, there is a significant positive sign of the coefficient of the GDP growth variable, as it was hypothesized. Inflation positively affects the use of trade credit. This is consistent with a research on determinants of trade credit by Demirgüç-Kunt and Maksimovic (2001) as well as with a part of the research by Hill et al. (2017).

The legal system is confirmed as a significant determinant of trade credit for Croatian SMEs. As it was expected, the coefficient has a negative sign. This implies that improvements in the legal system result in the reduction of trade credit. The findings are in line with previous research by Demirgüç-Kunt and Maksimovic (2001), Hill et al. (2017) and Palacín-Sánchez et al. (2018).

The results obtained from the dynamic panel analysis confirm our hypothesis that firm-specific (internal) factors as well as institutional and macroeconomic (external) factors affect the use of trade credit as a financing source of SMEs.

\section{CONCLUSION}

The paper examines the determinants of trade credit as a financing source among SMEs in Croatia. This topic is of importance for SME performance, especially considering difficulties they face in obtaining financing through financial intermediaries. However, similar empirical analyses are relatively rarely performed in the context of South-East European countries that face different conditions and have different institutional characteristics than the usually investigated countries. 
Thus, the aim of the paper was to reveal the influential factors - both firm-specific and countryspecific, that affect the use of trade credit, and to detect whether they differ in comparison to the factors observed in developed countries. Additionally, we were also interested in analysing whether trade credit substitute or complement other financing sources. The research sample included 1,225 SMEs operating in the 2008-2017 period and a dynamic panel methodology was applied.

The impact of analysed explanatory variables is in line with theoretical expectations. The results confirm that more profitable SMEs and those that generate more internal finance demand less trade credit. This confirms the hierarchy of preferences in financing ("pecking order") due to which costly trade credit financing is a less desirable source. Firms with larger inventories and growth opportunities use trade credit more to finance their investments in working capital. However, the coefficient for the latter, although positive, is not statistically significant. With regard to firm size, it can be concluded that larger and thus more creditworthy firms, that have better access to other financing sources, use less trade credit. Smaller firms, on the other hand, tend to rely more on trade credit due to their higher degree of information asymmetry and their inability to satisfy restrictive criteria requested from the financial institutions.

Distinguishing between short-term and long-term debt, the analysis aims at disclosing the relationship between trade credit and the availability of other financing sources. The negative coefficients with regard to short-term and long term-debt indicate a substitutive relation between trade credit and financing alternatives. The availability of short-term debt may reduce the need for trade credit, which is more costly and thus less preferable. This means that alternative external financing options affect the use of trade credit. The explanation is also valid for the long-term debt. However, this relationship is not statistically significant. Thus, this issue needs to be further examined.

As this substitution relation may be affected by the external conditions in the country, the analysis was extended to include country-level factors that control these external conditions and capture the changes in bank loans supply side. Among country-level factors, the efficiency of the banking sector, GDP growth, inflation and legal system determine the trade credit of Croatian SMEs. Higher efficiency of the banking system reduces the cost of borrowing from banks, resulting in a reduction of trade credit. Economic growth encourages firms to use trade credits. In a situation of a shortterm monetary instability in comparison to the long-term one, the sources of financing are more available, implying an increase of trade credit financing. As suppliers are more able to cope with problems in repaying loans from their customers in comparison to banks in a situation of a less efficient legal system, the importance of trade credit increases.

It can be concluded that trade credit use among SMEs in Croatia is determined by both firmspecific and country-specific factors. The observed results are similar to those confirmed in other comparable studies conducted in other European countries. The research results should contribute to a better understanding of the relevance that trade credit use has as a financing tool, especially considering the obstacles SMEs face with regard to the availability of alternative financing sources evident in the specific Croatian environment. 
For future research, it would be interesting to investigate more deeply the relationship between trade credit and alternative financing, especially long-term debt, as well as the rationale behind the decision to offer trade credit to customers. The research sample should be extended to include other South-East European countries in order to investigate and compare the influential trade credit factors in different institutional contexts. The effect of trade credit financing on the value of the company as well as on the probability of its survival could also be researched in the future.

\section{REFERENCES}

Agostino, M. and Trivieri, F. (2014) "Does trade credit play a signaling role? Some evidence from SMEs microdata", Small Business Economics, 42(1), pp. 131-151. https://doi.org/10.1007/s11187-013-9478-8

Alpeza, M., Oberman, M. and Has, M. (2018)Small and Medium Enterprises Report -Croatia 2018, SMEs and Entrepreneurship Policy Center (CEPOR), http://www.cepor.hr/wp-content/uploads/2015/04/EN-SME-Report-2018-za-web.pdf [Accessed 8.12.2019.]

Andrieu, G., Staglianò, R. and van der Zwan, P. (2018) "Bank debt and trade credit for SMEs in Europe: firm, industry-, and country-level determinants", Small Business Economics, 51(1), pp. 245-264. https://doi.org/10.1007/s11187-017-9926-y

Atanasova, C. (2007) "Access to institutional finance and the use of trade credit", Financial management, 36(1), pp. $49-67$. https://doi.org/10.1111/j.1755-053X.2007.tb00164.x

Baltagi, B.H. (2008) Econometric Analysis of Panel Data, 4th ed., Chester: John Wiley and Sons.

Bărbuță-Mişu, N. (2018) "Analysis of factors influencing managerial decision to use trade credit in construction sector", Economic research-Ekonomska istraživanja, 31(1), pp. 1903-1922. https://doi.org/10.1080/1331677X.2018.1504690

Beck, T., Demirguc-Kunt, A. and Maksimovic,V. (2008) "Financing patterns around the world: The role of institutions", Journal of Financial Economics, 89(3), pp. 467-487. https://doi.org/10.1016/j.jfineco.2007.10.005

Biais, B. and Gollier, C. (1997) “Trade credit and credit rationing”, Review of Financial Studies, 10(4), pp. 903-957. https://doi. org/10.1093/rfs/10.4.903

Blundell, R. and Bond, S. (1998) "Initial conditions and moment restrictions in dynamic panel data models", Journal of Econometrics, 87,(1), pp. 115-143. https://doi.org/10.1920/wp.ifs.1995.9517

Bussoli, C. (2017) "Trade Credit Financing: Substitution and Matching Effect for Italian SMEs", European Journal of Economics, Finance, and Administrative Sciences, 93, http://www.europeanjournalofeconomics financeandadministrativesciences.com/issues/PDF/EJEFAS_93_10.pdf [Accessed 13.09.2019.]

Bussoli, C. and Marino, F. (2018) "Trade Credit in Times of Crisis: Evidence from European SMEs", Journal of Small Business and Enterprise Development, 25(2), pp. 277-293, https://doi.org/10.1108//SBED-08-2017-0249

Canto-Cuevas, F., Palacin-Sancez, M. and Di Pietro, F. (2019) “Trade Credit as a Sustainable Resource during an SME's Life Cycle", Sustainability, 11(3), pp. 670-685, https://doi.org/10.3390/su11030670

Carbó-Valverde, S., Rodríguez-Fernández, F. and Udell, G. F. (2016) “Trade credit, the financial crisis, and firm access to finance”, Journal of Money, Credit and Banking, 48(1), pp. 113-143. https://doi.org/10.1111/jmcb.1229

Casey, E. and O'Toole, C. M. (2014) "Bank lending constraints, trade credit and alternative financing during the financial crisis: evidence from European SMEs", Journal of Corporate Finance, 27(C), pp. 173-193. https://doi.org/10.1016/j. jcorpfin.2014.05.001

Cuñat, V. (2007) „Trade Credit: Suppliers as Debt Collectors and Insurance Providers“, The Review of Financial Studies, 20(2), pp. 491-527, https:// doi:10.1093/rfs/hhl015

Deari, N. and Bărbuță-Mişu, N. (2018) “The Determinants of Trade Credit for Firms Listed on the Zagreb Stock Exchange: An Empirical Analysis“. ICTERI Workshops, http://ceur-ws.org/Vol-2104/paper_207.pdf [Accessed 01.10.2019.] 


\section{S. Pepur, D. Kovač, M. Curak: Factors Behind Trade Credit Financing of SMEs in Croatia Zbornik Veleučilišta u Rijeci, Vol. 8 (2020), No. 1, pp. 59-76}

Deloof, M. and La Rocca, M. (2015) "Local financial development and the trade credit policy of Italian SMEs ", Small Business Economics”, 44(4), pp. 905-924. https://doi.org/10.1007/s11187-014-9617-x

Deloof, M. and Jegers, M. (1996) “Trade Credit, Product Quality and Intragroup Trade: Some European Evidence”, Financial Management, 25 (3), pp. 33-43. https://doi.org/10.2307/3665806

Demirgüç-Kunt, A. and Maksimovic, V. (1998) “Law, Finance, and Firm Growth”, The Journal of Finance, 53(6), pp. $2107-2137$. https://doi.org/10.1111/0022-1082.00084

Demirgüç-Kunt, A. and Maksimovic, V. (2001) “Firms as financial intermediaries: evidence from trade credit data”, World Bank Working Paper. https://doi.org/10.1596/1813-9450-2696

Elliehausen, G. E. and Wolken, J.D. (2003), The Demand for Trade Credit: An Investigation of Motives of Trade Credit Use by Small Businesses, Board of Governors of the Federal Reserve Study

Emery, G. (1984) “A pure financial explanation of trade credit”, Journal of Financial and Quantitative Analysis, 19, pp. 271-285. https://doi.org/10.2307/2331090

Emery, G. (1987) "An optimal financial response to variable demand", Journal of Financial and Quantitative Analysis, 22, pp. 209-225. https://doi.org/10.2307/2330713

European Commission (2018) Annual report on European SMEs 2017/2018: SME Growing Beyond Borders, https:// ec.europa.eu/growth/smes/business-friendly-environment/performance-review_en [Accessed 23.09.2019.]

Ferris, J. S. (1981) "A transaction theory of trade credit use", Quarterly Journal of Economics, 96, pp. 243-270

Financijska agencija (2017). Analiza financijskih rezultata poslovanja poduzetnika Republike Hrvatske po županijama u 2017. godini, https://www.fina.hr/documents/52450/130232/Analiza+financijskih+rezultata+poslovanja+poduzetnika+po+ zupanijama+u+2017.+godini.pdf/14052190-596f-1937-203a-9b1806c4aa05? $\mathrm{t}=1573203186429$ [Accessed 10.12.2019.]

Fisman, R. and Love, I. (2003) "Trade credit, financial intermediary development and industry growth", Journal of Finance, 58(1), pp. 353-374. https://doi.org/10.1111/1540-6261.00527

García-Teruel, PJ. and Martínez-Solano, P. (2010) “Determinants of trade credit: A comparative study of European SMEs", International Small Business Journal, 28(3), pp. 215-233. https://doi.org/10.1177/0266242609360603

García-Teruel, P. J. and Martínez-Solano, P. (2010) "A dynamic perspective on the determinants of accounts payable", Review of Quantitative Finance and Accounting, 34(4), pp. 439-457. https://doi.org/10.1007/s11156-009-0124-0

Harc, M., Basarac Sertić, M., Andabaka, A. (2017) "Financial Resource Availability and Financing Needs of SMEs in EU28 and Croatia“ In: Tipurić, D., Galetić, F. (ed.), The Paradoxes of Leadership and Governance in the Postmodern Society, Zagreb: CIRU - Governance Research and Development Centre

Hill, M. D. et al. (2017) "Trade Credit or Financial Credit? An International Study of the Choice and Its Influences", Emerging Markets Finance and Trade, 53(10), pp. 2318-2332. https://doi.org/10.1080/1540496X.2017.1319355

Hill, M. et al. (2019), «International evidence on the determinants of trade credit provision», Managerial Finance, 45(4), pp. 484-498. https://doi.org/10.1108/MF-07-2018-0295

Hsiao, C. (1985) "Benefits and limitations of panel data", Econometric Reviews, 4(1), pp. 121-174. https://doi. org/10.1080/07474938508800078

Hsiao, C. (2005) “Why panel data?”, The Singapore Economic Review, 50(2), pp. 143-154. http://dx.doi.org/10.2139/ssrn.820204

Huyghebaert, N., Van de Gucht, L. M. and Van Hulle, C. (2001), “The Demand for Debt Finance by Entrepreneurial Firms”, K.U. Lueven Department of Applied Economics, Working Paper No. 0110

Kling, G., Paul, S., and Gonis, E. (2014) “Cash holding, trade credit and access to short-term bank finance”, International Review of Financial Analysis, 32, pp. 123-131. https://doi.org/10.1016/j.irfa.2014.01.013

Lee, Y. W., Stowe, J. D. (1993) “Product Risk, Asymmetric Information, and Trade Credit”, Journal of Financial and Quantitative Analysis, 28, pp. 285-300. https://doi.org/10.2307/2331291

Leitner, S. M., Stehrer, R. (2015), “What Determines SMEs' Funding Obstacles to Bank Loans and Trade Credits”, The Vienna Institute for International Economic Studies, Working Paper, No. 114. 
Mateut, S., Mizen, P., Ziane, Y. (2015) „Inventory composition and trade credit", International Review of Financial Analysis, 42, pp. 434-446. https://doi.org/10.1016/j.irfa.2015.09.008

Myers, S. C., Myluf, N.S. (1984) „Corporate financing and investment decisions when firms have information investors do not have",Journal of Financial Economics, 13, pp. 575-592. https://doi.org/10.1016/0304-405X(84)90023-0

Myers, S.C. (1984)., "The capital structure puzzle",Journal of Finance, 39, pp. 575-592. https://doi.org/10.1111/j.1540-6261.1984. tb03646.x

Martinez-Sola, C., Garcia-Teruel, P.J., Martinez-Solano, P. (2014) "Trade Credit and SME profitability,"Small Business Economics, 42 (3), pp. 561-577. https://doi.org/10.1007/s11187-013-9491-y

Martinez-Sola, C., Garcia-Teruel, P.J. and Martinez-Solano, P. (2017) "SMEs Access to finance and the value of supplier financing", Spanish Journal of Finance and Accounting, 46(4), pp. 455-483. https://doi.org/10.1080/02102412.2017.1345196

Mättö, M., Niskanen, M. (2019) "Religion, national culture and cross-country differences in the use of trade credit", International Journal of Managerial Finance, 15 (3), pp. 350-370. https://doi.org/10.1108/JMF-06-2018-0172

McGuinness, G., Hogan, T. (2014) "Bank credit and trade credit: evidence from SMEs over the financial crisis", International Small Business Journal, 34(4), pp. 1-34. https://doi.org/10.1177/0266242614558314

McGuinness, G., Hogan, T., Powell, R. (2018) “European trade credit use and SME survival”, Journal of Corporate Finance, 49(C), pp. 81-103. https://doi.org/10.1016/j.jcorpfin.2017.12.005

Meltzer, A. H. (1960) "Mercantile credit, monetary policy, and size of firms", Review of Economics and Statistics, 42, pp. 429443. https://doi.org/10.2307/1925692

Nilsen, J. (2002) "Trade credit and the bank lending channel", Journal of Money, Credit and Banking, 34(1), pp. 227-253. http:// dx.doi.org/10.2139/ssrn.762468

Niskanen, J., Niskanen, M. (2006) "The determinants of corporate trade credit policies in bank-dominated financial environment: the case of Finnish small firms", European Financial Management, 12(1), pp. 81-102. https://doi. org/10.1111/j.1354-7798.2006.00311.x

Pagano, M. (1993) “Financial markets and growth - An overview”, European Economic Review, 37(2-3), pp. 613-622. https:// doi.org/10.1016/0014-2921(93)90051-B

Palacín-Sánchez, M. J., Canto-Cuevas, F. J., di-Pietro, F. (2018) "Trade credit versus bank credit: a simultaneous analysis in European SMEs", Small Business Economics, pp. 1-18. https://doi.org/10.1007/s11187-018-0101-x

Petersen, M.A., Rajan, R. G. (1997) "Trade credit: theories and evidence“, The Review of Financial Studies, 10(3), pp. 661-691, https://doi.org/10.1093/rfs/10.3.661.

Psillaki, M., Eleftheriou, K. (2015) "Trade credit, bank credit, and flight to quality: evidence from French SMEs", Journal of Small Business Management, 53(4), pp. 1219-1240. https://doi.org/10.1111/jsbm.12106

Roodman, D. (2009) "A note on the theme of too many instruments", Oxford Bulletin of Economics and statistics, 71(1), pp. 135-158. https://doi.org/10.1111/j.1468-0084.2008.00542.x

Taketa, K., Udell, G. F. (2007) "Lending channels and financial shocks: the case of small and medium-sized enterprise trade credit and the Japanese banking crisis", Monetary and Economic Studies, Bank of Japan.

Vidučić, Lj., Pepur, S., Šimić Šarić, M., (2018) Financijski menadžment, Zagreb:RRIF

Wilson, N., Summers, B. (2002) "Trade Credit Terms Offered by Small Firms: Survey Evidence and Empirical Analysis", Journal of Business Finance \& Accounting, 29(3), pp. 317-351. https://doi.org/10.1111/1468-5957.00434

Yazdanfar, D., Öhman, P. (2016) “The Impact of Trade Credit Use on Firm Profitability: Empirical Evidence From Sweden", Journal of Advances in Management Research, 13(2), pp. 116-129. https://doi.org/10.1108/JAMR-09-2015-0067

Yazdanfar, D., Öhman, P. (2017) "Substitute or Complement? The Use of Trade Credit as a Financing Source among SMEs", Management Research Review, 40(1), pp. 10-27. https://doi.org/10.1108/MRR-06-2015-0153 


\title{
ČIMBENICI KORIŠTENJA TRGOVAČKOG KREDITA U SME U HRVATSKOJ
}

\author{
Sandra Pepur \\ Dr. sc., docent, Sveučilište u Splitu, Ekonomski fakultet, Cvite Fiskovića 5, 21000 Split, Hrvatska; \\ e-mail: sandra.pepur@efst.hr \\ Dujam Kovač \\ Dr. sc., asistent, Sveučilište u Splitu, Ekonomski fakultet, Cvite Fiskovića 5, 21000 Split, Hrvatska; \\ e-mail:dujam.kovac@efst.hr \\ Marijana Ćurak \\ Dr. sc., redoviti profesor, Sveučilište u Splitu, Ekonomski fakultet, Cvite Fiskovića 5, 21000 Split, Hrvatska; \\ e-mail:marijana.curak@efst.hr
}

\section{SAŽETAK}

Mala i srednja poduzeća (SME) doprinose nacionalnom gospodarstvu u smislu zaposlenosti, dodane vrijednosti, znanja i inovacija. Međutim, poteškoće u pristupu vanjskim financijama pod prihvatljivim uvjetima, odgovarajućim rokovima i dovoljnim iznosima utječu na njihove potencijale, a u slučaju ekonomskih nestabilnosti čak i na njihov opstanak. U situaciji informacijske asimetrije, uslijed koje su SME-i osjetljiviji na tržišne nesavršenosti, trgovački kredit može biti vrijedan izvor financiranja. U Europskoj uniji trgovački kredit je jedan on najznačajnijih vanjskih izvora financiranja i jedan je od najvažnijih alternativa financiranju putem financijskih posrednika. Međutim, među zemljama postoje značajne razlike u dostupnosti i korištenju trgovačkog kredita. Stoga ovo istraživanje ispituje čimbenike (specifične za poduzeća i specifične za zemlju) koji utječu na korištenje trgovačkog kredita kao izvora financiranja u Hrvatskoj. Empirijska analiza temelji se na podacima za 1225 malih i srednjih poduzeća koja su poslovala u Hrvatskoj u razdoblju od 2008. do 2017. te na korištenju panel metodologije. Rezultati potvrđuju da obilježja poduzeća, kao i značajke financijskog, makroekonomskog i institucionalnog okruženja u kojemu tvrtke djeluju, utječu na korištenje trgovačkog kredita kao izvora financiranja SME-a u Hrvatskoj. Rad doprinosi relativno oskudnom broju empirijskih potvrda odrednica trgovačkog kredita od strane SME-a u zemljama Srednjoistočne Europe.

Ključne riječi: financiranje od dobavljača, poduzeća u Hrvatskoj, panel metodologija 